\title{
Correction to: A Scoping Review of Economic Evaluations Alongside Randomised Controlled Trials of Home Monitoring in Chronic Disease Management
}

\author{
Kristian Kidholm $^{1}$ (D) Mie Borch Dahl Kristensen ${ }^{2}$
}

Published online: 13 October 2017

(C) Springer International Publishing AG 2017

\section{Correction to: Appl Health Econ Health Policy \\ DOI 10.1007/s40258-017-0351-9}

Table 2, 'Stoddart [19]' row: The cell entry in the 'Mean cost per control patient (SE)' column,

which reads:

1177 (1163.9)

should read:

11,768 (1163.9)

Table 2, 'Fasterholdt [24]' row: The cell entry in the 'Mean cost per control patient (SE)' column,

which reads:

15 (1618.0)

should read:

$14,724(1618.0)$

The online version of the original article can be found under doi:10.1007/s40258-017-0351-9.

Kristian Kidholm

kristian.kidholm@rsyd.dk

1 Centre for Innovative Medical Technology, Odense

University Hospital, 5000 Odense C, Denmark

2 MedCom, Forskerparken 10, 5230 Odense M, Denmark 